\title{
Water sorption and plasticization of an amorphous galacto-oligosaccharide mixture
}

\author{
Duarte P.M. Torres ${ }^{a, b, c, *}$, Margarida Bastos ${ }^{d}$, Maria do Pilar F. Gonçalves ${ }^{\mathrm{e}}$, \\ José A. Teixeirab ${ }^{b}$ Lígia R. Rodrigues $^{\mathrm{a}, \mathrm{b}}$ \\ a Biotempo - Biotechnology Consulting Ltd. Spinpark - Centro de Incubação de Base Tecnológica, Avepark, 4805-017 Guimarães, Portugal \\ ${ }^{\mathrm{b}}$ IBB - Institute for Biotechnology and Bioengineering, Centre of Biological Engineering, Universidade do Minho, 4710-057 Braga, Portugal \\ ${ }^{\mathrm{c}}$ Faculty of Nutrition and Food Sciences, University of Porto, Rua Dr. Roberto Frias, 4200-465 Porto, Portugal \\ d $C I Q(U P)$, Department of Chemistry, Faculty of Sciences (UP), R. Campo Alegre 687, P-4169-007 Porto, Portugal \\ ${ }^{\text {e } R E Q U I M T E, ~ D e p a r t a m e n t o ~ d e ~ E n g e n h a r i a ~ Q u i ́ m i c a, ~ F a c u l d a d e ~ d e ~ E n g e n h a r i a ~ d a ~ U n i v e r s i d a d e ~ d o ~ P o r t o, ~ R u a ~ D r . ~ R o b e r t o ~ F r i a s, ~} 4200-465$ Porto, Portugal
}

\section{A R T I C L E I N F O}

\section{Article history:}

Received 2 March 2010

Received in revised form 24 August 2010

Accepted 25 August 2010

\section{Keywords:}

Galacto-oligosaccharides

Food powders

Stability

Differential scanning calorimetry

Sorption isotherms

\begin{abstract}
A B S T R A C T
Food-grade galacto-oligosaccharides (GOS) are commercially available as transparent syrups or dried powders. Food powders can be found in an amorphous metastable state which is very sensitive to changes in temperature and moisture content. In this work the impact of water content on thermal behavior and relative humidity on water sorption behavior of amorphous GOS powders were studied. Results from differential scanning calorimetry (DSC) and sorption isotherms suggest that GOS mixture studied, with high content of oligosaccharides, has low ability to crystallize. A dramatic decrease in the stability of GOS powders occurred above critical water content (12-14 g/100 g) and corresponding critical water activity (0.55-0.62). Above these conditions GOS powder lost its amorphous character, collapsed and shrank, as the powder became a transparent "solution-like" material. The knowledge about the physicochemical changes, acquired during the present study, should be used to a proper control of processing and storage conditions to achieve and maintain optimum powder quality with desired properties.
\end{abstract}

(c) 2010 Elsevier Ltd. All rights reserved.

\section{Introduction}

Galacto-oligosaccharides (GOS) are mainly formed by enzymatic catalysis from lactose using the transgalactosylation catalytic activity of glycoside hydrolases (EC 3.2.1) to produce several oligomers of different chain lengths (De Roode, Franssen, van der Padt, \& Boom, 2003; Prenosil, Stuker, \& Bourne, 1987; Tzortzis \& Vulevic, 2009). Food-grade GOS are commercially available as transparent syrups or dried powders. In both cases they are mixtures containing oligosaccharides of different degrees of polymerization (galactose ${ }_{n}$-glucose), un-reacted lactose and generated monomer sugars (Playne \& Crittenden, 2009; Tzortzis \& Vulevic, 2009). Purified products with more than $90 \%$ (w/w) of GOS are commercially available from some manufacturers.

\footnotetext{
Abbreviations: $a_{\mathrm{w}}$, water activity; DP, degree of polymerization; $T_{\mathrm{g}}$, glass transition tempetrature; $T_{c}$, crystallization temperature; Gal, galactose; Glc, glucose; GOS, galacto-oligosaccharides.

* Corresponding author at: Biotempo - Biotechnology Consulting Ltd. Spinpark Centro de Incubação de Base Tecnológica, Avepark, 4805-017 Guimarães, Portugal. Tel.: +351253470 606; fax: +351253470607.

E-mail address: dtorres@biotempo.com (D.P.M. Torres).
}

Food powders can be found in an amorphous metastable state which is very sensitive to changes in temperature and moisture content. This amorphous matrix may exist either as a very viscous glass, or as a more liquid like "rubbery" amorphous structure. The change from the glassy state to the rubbery one occurs at glass transition temperature $\left(T_{\mathrm{g}}\right)$ which is specific for each material, but also depends on experimental variables (Roos \& Karel, 1991b). Above $T_{\mathrm{g}}$ the molecular mobility is greatly increased and many amorphous compounds crystallize. Therefore, the onset of crystallization may take place if either the temperature or the moisture content is increased (Roos \& Karel, 1991b).

Sorption isotherms show the amount of water adsorbed as a function of steady state water activity $\left(a_{\mathrm{w}}\right)$, at a constant temperature (Roos, 1995b). It is known that plasticizers like water cause a dramatic decrease in $T_{\mathrm{g}}$ (Roos, 1995b; Roos \& Karel, 1991b). The knowledge of the material sorption isotherm is extremely important to predict stability and quality changes during the process and storage of a food product.

Stickiness and caking are phenomena that may occur when amorphous food are heated or exposed to high humidity. These phenomena can be a consequence of the softening of powders above their $T_{\mathrm{g}}$ (Adhikari, Howes, Bhandari, \& Truong, 2001; Roos, 1995a). Furthermore, stickiness and caking are frequently 
undesirable during manufacturing operations causing lower product yields and operational problems.

The aim of this work is to study the impact of process variables (temperature and relative humidity) on the thermal and water sorption behavior of amorphous GOS powders in order to define processing and storage conditions to achieve and maintain optimum powder quality with desired properties.

\section{Materials and methods}

\subsection{Amorphous powders}

Lactose was purchased from Hi-Media (>99.5\% w/w) and GOS were provided by Biotempo, Biotechnology Consulting Ltd. (Portugal). The GOS mixture was produced in a bioreactor by enzymatic transgalactosylation during yeast growth in a lactose containing medium. The chemical characterization of the sample was previously conducted (unpublished data). Briefly, it has about $97 \%(w / w)$ of GOS (47\% trisaccharides, $42 \%$ tetrasaccharides and $8 \%$ pentasaccharides), mainly, $\beta 1 \rightarrow 4$ and $\beta 1 \rightarrow 6$ linked products.

Amorphous powders were obtained by freeze-drying. For that purpose, lactose and GOS were dissolved in distilled water $(15 \%$ $\mathrm{w} / \mathrm{v}$ ). Both solutions were frozen immediately after preparation at $-196^{\circ} \mathrm{C}$, in liquid nitrogen, for $15 \mathrm{~min}$. Afterwards, samples were freeze-dried at below 0.1 mbar. Then, samples were immediately pulverized using mortar and pestle and transferred into a vacuum desiccator, and dried over phosphorus pentoxide $\left(\mathrm{P}_{2} \mathrm{O}_{5}\right)$ for at least seven days.

\subsection{Moisture determination}

The initial water content of the samples was determined using a Karl-Fisher coulometer 737 (Methrohm, Switzerland). Samples were dissolved in dimethyl sulfoxide (DMSO) and the water content of the pure solvent was used as blank. Each sample was analyzed six times and the average value was taken as being the initial water content.

\subsection{Differential scanning calorimetry}

Differential scanning calorimetry (DSC) was used to determine $T_{\mathrm{g}}$ and crystallization temperature $\left(T_{\mathrm{C}}\right)$ as a function of the water content. The instrument used was a DSC 141, SETARAM (Caluire, France). Hermetically sealed steal cells were used in all measurements. An empty (air) steal cell was used as reference sample. The DSC was calibrated chemically for temperature and heat flow at a scan rate of $3^{\circ} \mathrm{C} / \mathrm{min}$, by use of tin $\left(\mathrm{mp} 231.9^{\circ} \mathrm{C}, \Delta H_{\mathrm{m}} 60.2 \mathrm{Jg}^{-1}\right)$, indium (mp $156.6^{\circ} \mathrm{C}, \Delta H_{\mathrm{m}} 28.4 \mathrm{Jg}^{-1}$ ), benzoic acid (mp $122.4^{\circ} \mathrm{C}$, $\left.\Delta H_{\mathrm{m}} 147.9 \mathrm{Jg}^{-1}\right)$, naphthalene $\left(\mathrm{mp} 80.2^{\circ} \mathrm{C}, \Delta H_{\mathrm{m}} 148.7 \mathrm{Jg}^{-1}\right)$, and o-terphenyl $\left(\mathrm{mp} 58.0^{\circ} \mathrm{C}, \Delta H_{\mathrm{m}} 74.6 \mathrm{~J} \mathrm{~g}^{-1}\right)$.

The Setaram software, SETSOFT, was used for determination of $T_{\mathrm{g}}, T_{\mathrm{c}}$ and transition enthalpy $(\Delta H)$.

\subsection{Sample preparation for differential scanning calorimetry}

Completely dry samples were placed in DSC cells (15-20 mg) and hermetically sealed. Samples of varying water contents were prepared by the following method: $15-20 \mathrm{mg}$ of dried material was weighted into DSC pans in a Microbalance Mettler-Toledo (readability $0.1 \mu \mathrm{g}$ ). The open cells were stored over a saturated $\mathrm{MgCl}_{2}$ solution (equilibrium relative humidity of air $(\mathrm{RH})$ of $33 \%$ at $25^{\circ} \mathrm{C}$ ), for varying periods at room temperature. With this procedure, samples with different moisture contents were obtained. At a given time cells were sealed and reweighted. Water content was determined from weight gain after equilibration. This procedure was repeated twice with independent samples.

\subsection{DSC measurements}

The samples were heated at $3^{\circ} \mathrm{C} / \mathrm{min}$ from $T_{\mathrm{g}}-30$ to $200^{\circ} \mathrm{C}$. Thermograms were analysed in order to obtain $T_{\mathrm{g}}$ (determined as the temperature of onset of an endothermic shift in apparent specific heat), and $T_{\mathrm{c}}$ (determined as the temperature of onset of an exothermic peak).

The Gordon and Taylor equation (Gordon \& Taylor, 1952) was fitted to the experimental $T_{\mathrm{g}}$ data according to Eq. (1):

$T_{\mathrm{g}}=\frac{w_{1} T_{\mathrm{g} 1}+k w_{2} T_{\mathrm{g} 2}}{w_{1}+k w_{2}}$

where $w_{1}$ and $w_{2}$ are the weight fraction of the solute and water respectively; $T_{\mathrm{g} 1}$ is the $T_{\mathrm{g}}$ of anhydrous solute; $T_{\mathrm{g} 2}$ is the $T_{\mathrm{g}}$ of amorphous water; and $k$ is a constant. A $T_{\mathrm{g}}$ of $-135^{\circ} \mathrm{C}$ was used for water (Johari, Hallbrucker, \& Mayer, 1987). The Gordon and Taylor (Eq. (1)) is generally used for predicting the water plasticization in binary systems. Therefore, Eq. (1) was used in the present study to predict the water plasticization of lactose and GOS, considering that all solid components contributing to the observed glass transition were miscible and formed a single phase (Roos, 2009).

Root mean square deviation (in percentage) (RSM) was calculated as an indication of the goodness of fit of the model to the experimental data according to Eq. (2),

$\% \mathrm{RSM}=\sqrt{\frac{\sum_{i}^{N}\left[\left(y_{i}-y_{i}^{*}\right) / y_{i}\right]^{2}}{N}} \times 100$

where $y_{i}$ is the experimental value; $y_{i}{ }^{*}$ is the calculated value according to Eq. (1) and $N$ is the number of experimental points.

\subsection{Sorption isotherms}

Measurement of water uptake by the initially dried sugars was determined periodically from changes in weight of the samples kept at room temperature $\left(20-21^{\circ} \mathrm{C}\right)$ in different saturated salt solutions to maintain a constant relative humidity (Table 1 ). Approximately $0.1 \mathrm{~g}$ of dry sample was weighted into a constructed aluminium foil pan ( $20 \mathrm{~mm}$ diameter $\times 15 \mathrm{~mm}$ height). The samples were weighted every $12 \mathrm{~h}$. Water content was determined from weight gain after equilibration. This procedure was performed in triplicate.

During the determination of the sorption isotherms, it is assumed that, at a steady state, the ratio of the vapour pressure in food, $p$, and that of pure water, $p_{0}$, equals water activity, $a_{\mathrm{w}}$. The relative vapour pressure of water in food and in the surrounding atmosphere is also equal, and therefore water activity may be obtained from RH of $\operatorname{air}\left(p / p_{0}=a_{\mathrm{w}}=\mathrm{RH} / 100\right)$ (Roos, 1995b).

Previously, the Guggenheim-Anderson-de Boer (GAB) (van den Berg \& Bruin, 1981) water sorption model (Eq. (3)) has proved to fit to water sorption data of most food materials. This model can be used to determine the sorption isotherms, providing the relationship between $a_{\mathrm{w}}$ and moisture content $(m)$.

$\frac{m}{m_{\mathrm{m}}}=\frac{C K^{\prime} a_{\mathrm{w}}}{\left(1-K^{\prime} a_{\mathrm{w}}\right)\left(1-K^{\prime} a_{\mathrm{w}}+C K^{\prime} a_{\mathrm{w}}\right)}$

Table 1

Equilibrium relative humidity ( $\mathrm{RH}$ ) of saturated salt solutions at $20^{\circ} \mathrm{C}$ (Greenspan, 1977; 6).

\begin{tabular}{lcll}
\hline & $\mathrm{RH}(\%)$ & $\mathrm{RH}(\%)$ \\
\hline $\mathrm{P}_{2} \mathrm{O}_{5}$ & 0.0 & $\mathrm{NaBr}$ & 59.1 \\
$\mathrm{LiCl}$ & 11.3 & $\mathrm{SrCl}_{2}$ & 72.5 \\
$\mathrm{MgCl}_{2}$ & 33.1 & $\mathrm{NaCl}$ & 75.5 \\
$\mathrm{~K}_{2} \mathrm{CO}_{3}$ & 43.2 & $\left(\mathrm{NH}_{4}\right)_{2} \mathrm{SO}_{4}$ & 81.3 \\
$\mathrm{Mg}\left(\mathrm{NO}_{3}\right)_{2}$ & 54.4 & $\mathrm{KCl}$ & 85.1 \\
\hline
\end{tabular}


Additionally, a second-order polynomial model (Eq. (4)) was suggested by other authors (Bizot, 1983; Roos, 1993).

$\frac{\alpha_{\mathrm{w}}}{m}=\alpha \alpha_{\mathrm{w}}^{2}+\beta \alpha_{\mathrm{w}}+\gamma$

where $\alpha=\frac{K^{\prime}}{m_{\mathrm{m}}((1 / C)-1)}, \beta=\frac{1}{m_{\mathrm{m}}(1-(2 / C))}$, and $\gamma=\frac{1}{C K^{\prime} m_{\mathrm{m}}}$

The GAB isotherm parameters were determined by plotting $a_{\mathrm{w}} / m$ against $a_{\mathrm{w}}$. The constants $\alpha, \beta$, and $\gamma$ in Eq. (4) were calculated by quadratic minimum squares regression analysis. The experimental sorption data in $a_{\mathrm{w}}$ range from 0.113 to 0.432 for amorphous lactose, and 0.113 to 0.850 for amorphous GOS, were used to obtain the constant values. Constants $C$ and $K^{\prime}$ and monolayer value $\left(m_{\mathrm{m}}\right)$ were calculated from Eqs. (5)-(7), respectively.

$C=\frac{1}{m_{\mathrm{m}} \gamma K^{\prime}}$

$K^{\prime}=\frac{\beta-\left(1 / m_{m}\right)}{-2 \gamma}$

$m_{\mathrm{m}}^{2}=-\frac{1}{4 \alpha \gamma-\beta^{2}}$

RMS values (Eq. (2)) were calculated as an indication of the goodness of fit of the tested models to our data.

\subsection{Statistics}

The $t$ test was used to compare moisture content of GOS and lactose at different $a_{\mathrm{w}}$. The level of confidence required for significance was selected as $P \leq 0.05$.

\section{Results and discussion}

\subsection{Effect of moisture content on glass transition temperature}

Lactose showed a typical thermal behaviour of amorphous materials, and therefore the glass transition and crystallization parameters could be determined. However, in the thermogram of the GOS mixture, no exothermic peak was observed at any moisture content (Fig. 1). This observation suggests that the crystallization rate of GOS mixture is very slow or negligible in the studied experimental conditions. The GOS sample is a mixture containing mainly linear tri-, tetra-, and pentasaccharides (as described). As a timedependent phenomenon, crystallization can be impaired by higher molecular sizes that contribute to higher viscosity and slow diffusion (Roos, 1995a). There is a lack of studies in the literature

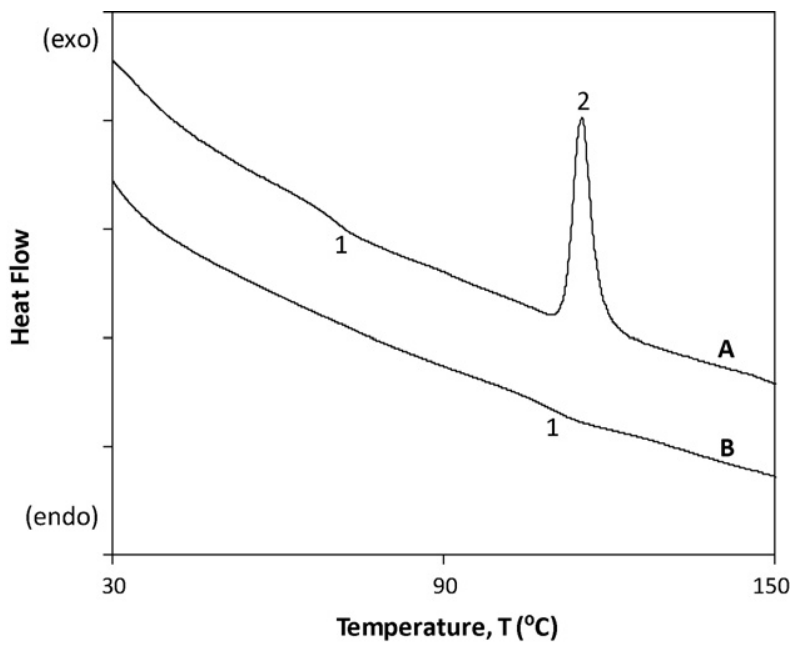

Fig. 1. Typical DSC thermograms for amorphous lactose (A) and amorphous GOS (B) 1 , glass transition; 2 , crystallization. Scanning rate was $3^{\circ} \mathrm{C} / \mathrm{min}$.

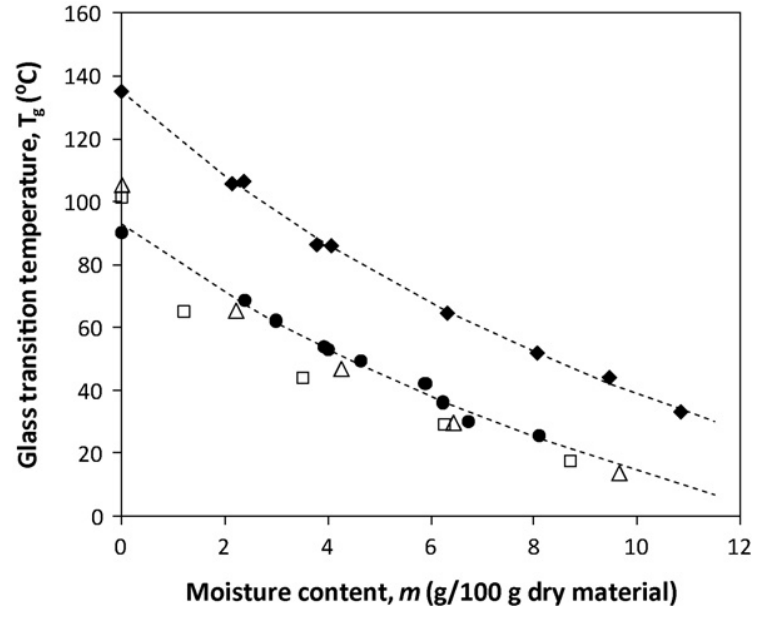

Fig. 2. Effect of moisture content of amorphous food materials on glass transition temperatures. $\bullet$, Amorphous lactose (this work); $\downarrow$, amorphous GOS (this work). Dashed lines represent the fitting of the Gordon and Taylor equation to the experimental data. Other data for amorphous lactose was extracted from the literature, $\Delta$ (Roos \& Karel, 1990) and $\square$ (Haque \& Roos, 2004) and is superimposed for comparison.

relating the polymerization degree with the crystallization ability of oligosaccharides. However, it was observed a reduction in the growth rate of sucrose crystals when different oligosaccharides from corn syrup were mixed with sucrose (Tjuradi \& Hartel, 1995).

The effect of moisture content in $T_{\mathrm{g}}$ for both materials is shown in Fig. 2 along with the glass transition temperatures obtained for lactose that have been reported in the literature. It was observed a drastic decrease of $T_{\mathrm{g}}$ with the increasing water content. This is a typical behaviour of water plasticization that has also been reported in other studies (Haque \& Roos, 2004; Roos \& Karel, 1991b; Zimeri \& Kokini, 2002). The experimental $T_{\mathrm{g}}$ within the moisture content range from 0 to $8.1 \mathrm{~g}$ of water/100 $\mathrm{g}$ dry material for lactose; and from 0 to $10.8 \mathrm{~g}$ of water/100 $\mathrm{g}$ dry material for GOS was successfully predicted by the Gordon and Taylor equation as shown in Fig. 2. The data suggest that a similar water plasticization effect occurs in binary systems water/lactose and water/GOS. The determined constant $k$ was 5.3 (RSM, 4.6\%) and 5.5 (RSM, 1.9\%) for lactose and GOS, respectively.

Furthermore, $T_{\mathrm{g}}$ values of GOS were considerably higher than the ones observed for lactose (Fig. 2). Completely dry lactose and GOS have $T_{\mathrm{g}}$ values of 90.3 and $135.1^{\circ} \mathrm{C}$, respectively. $T_{\mathrm{g}}$ value for GOS mixture is between the $T_{\mathrm{g}}$ values reported to maltotetraose and maltopentose (Roos \& Karel, 1991a). An increase in $T_{\mathrm{g}}$ of glucose homopolymers (maltodextrins) with increasing molecular weight has been reported (Roos \& Karel, 1991a). This behaviour is described by the relation previously established by Fox and Flory for polystyrene homopolymers (Fox \& Paul, 1950). It is important to notice that in this study it was not possible to determine a relation between molecular weight and $T_{\mathrm{g}}$ of GOS, because of the polydispersity of the sample. However, since GOS are homopolymers of aldohexoses, a similar effect of its molecular weight on $T_{\mathrm{g}}$ is expected to occur.

\subsection{Water sorption}

The moisture content, at various $a_{\mathrm{w}}$, sorbed by amorphous lactose and GOS at equilibrium after $144 \mathrm{~h}$ of storage, is given in Table 2. The amount of water sorbed by lactose is significantly lower $(P \leq 0.05)$, comparing to that of GOS, at $a_{\mathrm{w}}$ from 0.331 to 0.851 .

Lactose sorption isotherm shows a dramatic decrease in sorbed water when $a_{\mathrm{w}}>0.432$ (Table 2 and Fig. 3 ). As observed by other authors, this phenomenon is a result of lactose crystallization 
Table 2

Moisture contents (g/100 g dry material) of lactose and GOS stored for $144 \mathrm{~h}$ at various $a_{\mathrm{w}}$ at room temperature (mean \pm standard deviation)

\begin{tabular}{llr}
\hline$a_{\mathrm{w}}$ & \multicolumn{1}{l}{ Lactose } & \multicolumn{1}{c}{ GOS } \\
\hline 0.113 & $2.09 \pm 0.19^{*}$ & $2.55 \pm 0.15^{*}$ \\
0.331 & $5.34 \pm 0.16$ & $6.24 \pm 0.07$ \\
0.432 & $7.10 \pm 0.07$ & $7.81 \pm 0.09$ \\
0.544 & $0.12 \pm 0.09$ & $9.94 \pm 0.08$ \\
0.591 & $0.41 \pm 0.29$ & $12.29 \pm 0.18$ \\
0.725 & $0.65 \pm 0.06$ & $20.87 \pm 0.58$ \\
0.755 & $0.82 \pm 0.29$ & $22.68 \pm 0.80$ \\
0.813 & $0.91 \pm 0.12$ & $29.58 \pm 0.17$ \\
0.851 & $1.21 \pm 0.04$ & $37.59 \pm 0.69$ \\
\hline
\end{tabular}

* Not statistically different $(P=0.056)$. Significant differences $(P \leq 0.05)$ were observed between moistures content of lactose and GOS stored at $a_{w}>0.113$.

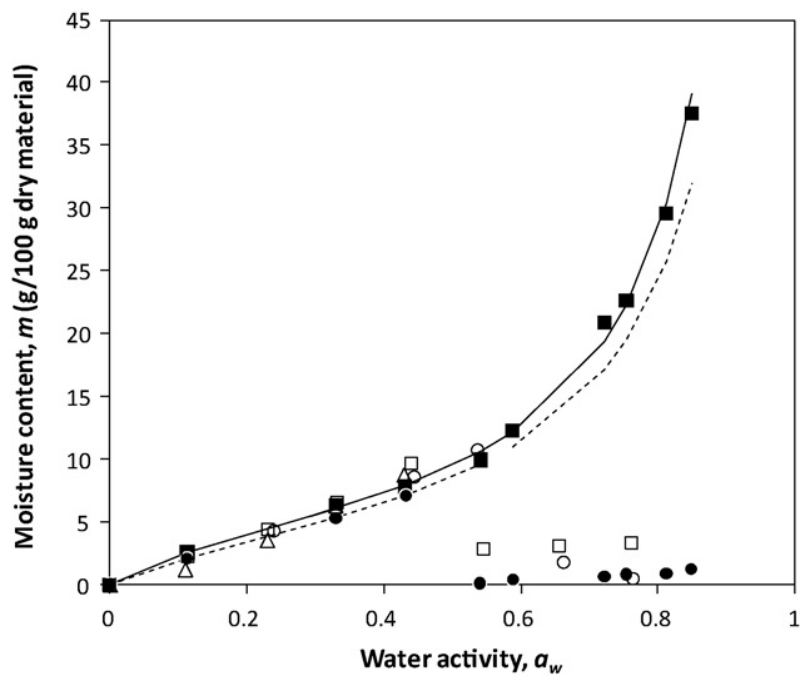

Fig. 3. Water sorption isotherms of lactose and GOS stored for $144 \mathrm{~h}$ at room temperature $\left(20-21^{\circ} \mathrm{C}\right)$ using experimental data from the present work $(\bullet$, lactose and $\square$, GOS). Full and dashed lines represent the fitting of the GAB model to the experimental data of GOS and lactose, respectively. Other experimental data for amorphous lactose was extracted from the literature and superimposed for comparison: $\triangle$ amorphous lyophilized lactose stored for $24 \mathrm{~h}$ at room temperature (Roos $\&$ Karel, 1991b); $\square$, amorphous, spray dried lactose (coarse powder) stored for $144 \mathrm{~h}$ at room temperature $\left(22-23^{\circ} \mathrm{C}\right.$ ) (Haque \& Roos, 2004); $\bigcirc$, amorphous lyophilized lactose stored for $24 \mathrm{~h}$ at $24^{\circ} \mathrm{C}$ (Jouppila \& Roos, 1994).

and consequent release of adsorbed water (Haque \& Roos, 2004; Jouppila \& Roos, 1994; Roos \& Karel, 1991b). When $a_{\mathrm{w}}>0.432$ changes in structural properties of lactose powder were also observed, namely, collapse and shrinkage.

Sorbed water by GOS increased within the full range of tested $a_{\mathrm{w}}$, suggesting that crystallization rate of GOS mixture is very slow or negligible in the studied experimental conditions. It is known that the time needed for crystallization depends on the material char- acteristics, including molecular size. As described, GOS mixture is mainly composed by tri-, tetra- and pentasaccharides. Probably, higher molecular sizes contribute to higher viscosity and slow diffusion, impairing crystallization. At $a_{\mathrm{w}} \geq 0.591$, GOS powder lost its amorphous character, collapsed and shrinked, and became a transparent "solution-like" material. It is important to stress that the sorption behaviour at $a_{\mathrm{w}}>0.432$ was the major difference observed between the two materials tested.

Comparing the results obtained in this study for the sorbed water content by lactose with other published works (Haque \& Roos, 2004; Jouppila \& Roos, 1994; Roos \& Karel, 1991b), small differences were observed, probably due to the drying procedures, particles size, storage time, and temperature.

The experimental water sorption data for amorphous lactose and amorphous GOS powders, in the $a_{\mathrm{w}}$ range shown in Table 3, were successfully modelled with the GAB isotherm model (Fig. 3). The materials showed the typical sigmoid water sorption isotherm (Roos, 1995b). The GAB monolayer value determined for GOS powder was slightly higher than the one for lactose powder. The monolayer value for lactose was $5.40 \mathrm{~g} / 100 \mathrm{~g}$ dry solids, which was close to the water content of $5.34 \mathrm{~g} / 100 \mathrm{~g}$ dry solid when stored at $a_{\mathrm{w}} 0.331$ at room temperature. The monolayer value for GOS was $5.49 \mathrm{~g} / 100 \mathrm{~g}$ dry solid, which was close to the water content of GOS when stored at $a_{\mathrm{w}} 0.296$ at room temperature. The GAB monolayer value for lactose reported in this study is higher than values reported for amorphous spray dried lactose (coarse powder) stored for $144 \mathrm{~h}$ at room temperature $\left(22-23^{\circ} \mathrm{C}\right.$ ) (Haque \& Roos, 2004) and for 3 weeks at $20-38^{\circ} \mathrm{C}$ (Bronlund \& Paterson, 2004); and lower than monolayer value for spray dried lactose stored for 3 weeks at $12^{\circ} \mathrm{C}$ (Bronlund \& Paterson, 2004) (Table 3). Hence, the values obtained fall well within other ones reported in the literature (Bronlund \& Paterson, 2004; Haque \& Roos, 2004; Jouppila \& Roos, 1994).

Water plasticization is an important factor contributing to the characteristics and storage stability of the GOS powders. A dramatic decrease in the stability of GOS powders occurred above critical water content and corresponding critical water activity. These values of critical water content (approximately, $14 \mathrm{~g} / 100 \mathrm{~g}$ ) and water activity (approximately 0.62 ) correspond to those at which the estimated glass transition of GOS occurs at the storage temperature (Fig. 4). However, during storage at room temperature, lower $a_{\mathrm{w}}$ values should be used, since it was observed that when $a_{\mathrm{w}} \geq 0.591$ (water content in equilibrium was $12.3 \mathrm{~g} / 100 \mathrm{~g}$, see Table 2) the GOS powder lost its amorphous character, collapsed and shrank as the powder became a transparent "solution-like" material.

Based on these results, it was possible to conclude that glass transition region at room temperature occurs for $a_{\mathrm{w}}$ between 0.55 and 0.62 and a water content between 12 and $14 \mathrm{~g} / 100 \mathrm{~g}$. Using the same methodology for amorphous lactose, the glass transition region at room temperature occurred for $a_{\mathrm{w}}$ between 0.45 and 0.50 and a water content between 8.0 and $8.7 \mathrm{~g} / 100 \mathrm{~g}$. Another study

Table 3

Monolayer value $\left(m_{\mathrm{m}}\right)$, and constants $K^{\prime}$ and $C$ for the GAB isotherms.

\begin{tabular}{|c|c|c|c|c|c|c|c|}
\hline Material & $a_{\mathrm{w}}$ & $n$ & $m_{\mathrm{m}}$ & $K^{\prime}$ & $C$ & \%RMS & Ref. \\
\hline Lactose & $0.113-0.432$ & 3 & 5.40 & 0.99 & 4.14 & 3.9 & This study \\
\hline Lactose & $0.115-0.444$ & 4 & 4.91 & 1.18 & 4.33 & & a \\
\hline Lactose & $0.114-0.441$ & 4 & 4.77 & 1.59 & 2.93 & 0.29 & $\mathrm{~b}$ \\
\hline Lactose & $0.114-0.441$ & 4 & 6.93 & 0.77 & 3.39 & & c \\
\hline Lactose & $0.114-0.441$ & 4 & 4.88 & 1.16 & 3.23 & & $\mathrm{~d}$ \\
\hline GOS & $0.113-0.851$ & 9 & 5.49 & 1.02 & 5.42 & 4.6 & This study \\
\hline
\end{tabular}

$n$, Number of experimental points. In this study each experimental point was made in triplicate.

a Amorphous lyophilized lactose stored for $24 \mathrm{~h}$ at $24^{\circ} \mathrm{C}$ (Jouppila \& Roos, 1994).

b Amorphous, spray dried lactose (coarse powder) stored for $144 \mathrm{~h}$ at room temperature $\left(22-23^{\circ} \mathrm{C}\right)($ Haque $\&$ Roos, 2004$)$.

c Amorphous, spray dried lactose stores for 3 weeks at $12{ }^{\circ} \mathrm{C}$ (Bronlund \& Paterson, 2004).

d Amorphous, spray dried lactose stores for 3 weeks at $20-38{ }^{\circ} \mathrm{C}$ (Bronlund \& Paterson, 2004). 


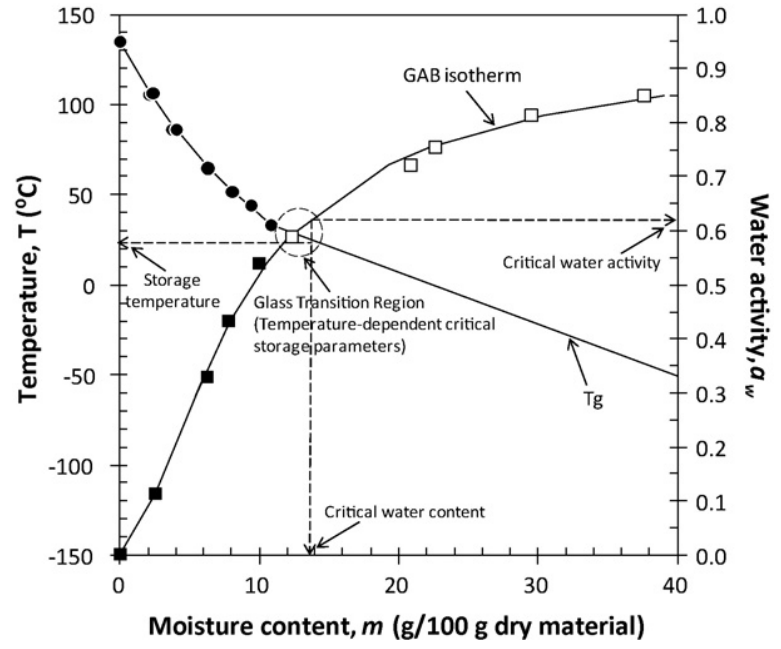

Fig. 4. Water plasticization and $T_{g}$ of the characterized GOS mixture, at various water contents. Depression of the $T_{\mathrm{g}}$ with water content was predicted by the Gordon and Taylor equation (1). The critical water content and water activity correspond to plasticization, depressing $T_{\mathrm{g}}$ to room temperature.

conducted for amorphous lactose reported a critical $a_{\mathrm{w}}$ around 0.37 and a critical water content around $7.5 \mathrm{~g} / 100 \mathrm{~g}$ (Roos, 2009). Again, the differences observed can be due to differences in drying procedures, particles size, storage time, and temperature.

\section{Conclusions}

Unlike amorphous lactose, that exhibits an exothermic peak during DSC measurements, no crystallization was observed during GOS heating at $3^{\circ} \mathrm{C} / \mathrm{min}$ until $200^{\circ} \mathrm{C}$. Furthermore, sorbed water by GOS was found to increase all the way within the range of $a_{\mathrm{w}}$ used, suggesting that GOS mixtures with high content of oligosaccharides have low ability to crystallize. This observation has an important impact in GOS applications and product development, since these ingredients can replace lactose or other sugars whenever crystal formation is undesirable.

Water plasticization is a key factor contributing to the characteristics and storage stability of the GOS powders. A dramatic decrease in the stability of GOS powders occurs above critical water content and corresponding critical water activity. GOS powder lost its amorphous character, collapsed and shrank as the powder became a transparent "solution-like" material. In summary, it is possible to conclude that the critical storage $a_{\mathrm{w}}$ is between 0.55 and 0.62 and the water content is between 12 and $14 \mathrm{~g} / 100 \mathrm{~g}$. These values are considerably higher than the critical $a_{\mathrm{w}}$ and the critical water content found for amorphous lactose.

\section{Acknowledgements}

The authors gratefully acknowledge the financial support of this study through the Project BIOLIFE - PRIME 03/347 by Agência da Inovação-Programa IDEIA (Portugal). Duarte P.M. Torres acknowledges to Fundação para a Ciência e a Tecnologia (Portugal) for financial support through the PhD grant (reference SFRH/BDE/15510/2004).

\section{References}

Adhikari, B., Howes, T., Bhandari, B. R., \& Truong, V. (2001). Stickiness in foods: A review of mechanisms and test methods. International Journal of Food Properties, 4(1), 1-33.

Bizot, H. (1983). Using the GAB model to construct sorption isotherms. In R. Jowitt, F. Escher, B. Hällstrom, H. F. T. Meffert, W. E. L. Spiess, \& G. Vos (Eds.), Physical properties of foods (pp. 43-54). London: Applied Science Publishers.

Bronlund, J., \& Paterson, T. (2004). Moisture sorption isotherms for crystalline, amorphous and predominantly crystalline lactose powders. International Dairy Journal, 14(3), 247-254.

De Roode, B. M., Franssen, A. C. R., van der Padt, A., \& Boom, R. M. (2003). Perspectives for the industrial enzymatic production of glycosides. Biotechnology Progress, 19(5), 1391-1402.

Fox, T. G. J., \& Paul, J. F. (1950). Second-order transition temperatures and related properties of polystyrene. I. Influence of molecular weight. Journal of Applied Physics, 21(6), 581-591.

Gordon, M., \& Taylor, J. S. (1952). Ideal copolymers and the 2nd-order transitions of synthetic rubbers. 1. Non-crystalline copolymers. Journal of Applied Chemistry, 2(9), 493-500.

Greenspan, L. (1977). Humidity fixed-points of binary saturated aqueous-solutions. Journal of Research of the National Bureau of Standards Section A-Physics and Chemistry, 81(1), 89-96.

Haque, M. K., \& Roos, Y. H. (2004). Water sorption and plasticization behavior of spray-dried lactose/protein mixtures. Journal of Food Science, 69(8), E384-E391.

Johari, G. P., Hallbrucker, A., \& Mayer, E. (1987). The glass liquid transition of hyperquenched water. Nature, 330(6148), 552-553.

Jouppila, K., \& Roos, Y. H. (1994). Water sorption and time-dependent phenomena of milk powders. Journal of Dairy Science, 77(7), 1798-1808.

Kitic, D., Jardim, D. C. P., Favetto, G. J., Resnik, S. L., \& Chirife, J. (1986). Theoretical prediction of the water activity of standard saturated salt-solutions at various temperatures. Journal of Food Science, 51(4), 1037-1041.

Playne, M. J., \& Crittenden, R. G. (2009). Galacto-oligosaccharides and other products derived from lactose. In P. L. H. McSweeney, \& P. F. Fox (Eds.), Lactose, water, salts and minor constituents (pp. 121-201). New York: Springer.

Prenosil, J. E., Stuker, E., \& Bourne, J. R. (1987). Formation of oligosaccharides during enzymatic lactose. 1. State of art. Biotechnology and Bioengineering, 30(9), 1019-1025.

Roos, Y. H. (1993). Water activity and physical state effects on amorphous food stability. Journal of Food Processing and Preservation, 16(6), 433-447.

Roos, Y. H. (1995a). Time-dependent phenomena. Phase transition in foods. London: Academic Press, Inc., pp. 193-245.

Roos, Y. H. (1995b). Water and phase transitions. Phase transition in foods. London: Academic Press, Inc., pp. 73-107.

Roos, Y. H. (2009). Solid and liquid states of lactose. In P. L. H. McSweeney, \& P. F. Fox (Eds.), Lactose, water, salts and minor constituents (pp. 17-33). New York: Springer.

Roos, Y. H., \& Karel, M. (1990). Differential scanning calorimetry study of phasetransitions affecting the quality of dehydrated materials. Biotechnology Progress, $6(2), 159-163$

Roos, Y. H., \& Karel, M. (1991a). Phase-transitions of mixtures of amorphous polysaccharides and sugars. Biotechnology Progress, 7(1), 49-53.

Roos, Y. H., \& Karel, M. (1991b). Plasticizing effect of water on thermal-behavior and crystallization of amorphous food models. Journal of Food Science, 56(1), 38-43.

Tjuradi, P., \& Hartel, R. W. (1995). Corn syrup oligosaccharide effects on sucrose crystallization. Journal of Food Science, 60(6), 1353-1356.

Tzortzis, G., \& Vulevic, J. (2009). Galacto-oligosaccharide prebiotics. In D. Charalampopoulos, \& R. A. Rastall (Eds.), Prebiotics and probiotics science and technology (pp. 207-244). New York: Springer.

van den Berg, C., \& Bruin, S. (1981). Water activity and its estimation in food systems: Theoretical aspects. In L. B. Rockland, \& G. F. Stewart (Eds.), Water activity: Influences on food quality (pp. 1-61). New York: Academic Press.

Zimeri, J. E., \& Kokini, J. L. (2002). The effect of moisture content on the crystallinity and glass transition temperature of inulin. Carbohydrate Polymers, 48(3), 299-304. 